\title{
Non - English Mayor Students' Attitudes Toward English Lesson at Batanghari University
}

\author{
Yanti Ismiyati $^{1}$, Ridho Praja Dinata ${ }^{2}$ \\ ${ }^{1,2}$ Faculty of Teacher Training and Education, Universitas Batanghari, Jambi, Indonesia
}

\begin{abstract}
This research is aimed at analyzing the attitude of students of non-English major study towards English lessons at the faculty of Economics and Law of Batanghari University in Jambi. The research problem is the attitude of students of non-English major study towards English lessons. The research is used quantitative method by using questionnaire and discussion method. Based on the calculation of the item values using SPSS, it was concluded that 40 questions were valid, 5 were invalid, the total score correlation value ( $r$ count) was consulted with rtable (0.349) at $\alpha=0.05,40$ questions were declared valid and as many as 5 questions were declared invalid namely question no. 7,18,19 2528 and the non-valite questionnaire was discarded. So the number of items used as research is as many as 40 questions. Based on table 4.3 above, can be seen an overview of each variable. Variable Attitute Height with an average value of 3.74. This means that Behavioral is in the High category which is in the High category with an average value of 3.88. Cognitive variable 3.97 and emotional included in the high category that is equal to 3.85. Variable of ATTITUDES of 10 statement items there is one item in the very high category (8) the rest, all items are in the high category with an average value in the range, 3.40 - 4.19 overall, Variable of ATTITUDES is in the category high with an average value of 3.86. Variable of BEHAVIORAL Of the 10 statement items there is one item in the very high category (8) the rest, all items are in the high category with the average value in the range, 3.40 - 4, 19 overall, the Variable of Behavioral is in the high category with an average value of 3.88.COGNITIVE out of the 10 statement items there is one item in the very high category (8) and the rest, all items are in the high category with an average value on range, 3.40 - 4.19 overall, QUESTIONAIRES OF COGNITIVES are in the high category with an average value of 3.97. EMOTIONAL OF 10 statement items there is one items are in the very high category (8) the rest, all items are in the high category with an average value in the range, $3.40-4.19$ overall, QUESTIONAIRES OF EMOTIONAL are in the high category with an average value of 3.85.
\end{abstract}

Keywords: Attitude, Behavioral, Cognitive, Emtional, English lesson.

\section{INTRODUCTION}

Teaching English then has a become a very popular dignity status nowadays. As an English lecturer, we are required to empower the human resources at university especially for students. They are able to comprehension and understand how to use language (English) well (Goodwyn and Branson, 2005). However, English has given the dilemma at the classroom activity, whether English as the foreign language as the foreign language should be taught Indonesian and English. Furthermore in Indonesia we need more time and process to comprehension and understand English. It mean that they have learned English for some many years.

They have experience started when they were in high school till university. Thus we can assume that they are able to achieve basic English as the foreign language. However, the students get the English lesson at university, they still use their Language One L1 (Indonesian) during the learning and teaching process at the class room activity. As one of the English lecturer at university. The researcher found that every lecturers has their own style and strategy when the give the English lesson. Sometimes they use Indonesian and English. So that is why the researcher wants to investigate the students attitude towards English for Economics at Economics faculty. The students get difficulty when they study English for economics. Meanwhile, the research about the attitude had been researched by many researcher from around the world, Kassain (2010) revealed that the response or the attitude of the students in Iranian undergraduates towards learning English were positively good. It means that the students were enthusiastic to study about it. Then, Koi ( 2012) found that the students were exemplary. In this case the researchers compared between students and teachers' attitude.

The researcher will conduct the research which will find their attitude towards economics English. The researcher investigates their attitude to know deeply about it and it will find the attitude of them in English. Magnuson (20014), claims that children's few years of life are crucial to the development of language and social skill school preparedness in these areas help students adjust to academics expectancies. The attitude of them toward English and how they do that is one of the important aspects in this research. The students quite difficulty when they understanding and comprehending the English economics such as, vocabulary, content of reading and tenses.

The attitude of the students on reading and others skill in English are not same. So that is why the researcher needs to find kind of aspects of that. Gibbon ( 2012), says that posited that one needs to be proficient in the use of English among non-native speakers has become a large scale phenomenon. Although many researchers believe that 
teaching English will give better result and improvement to the students, research on Indonesian students whose English as international

\section{REVIEW OF RELATED LITERATURE Method of Using Language English \\ Translation method}

The translation method or also knows as the grammar-translation method had been used since the nineteenth century. It is the most traditional approach in teaching English as the second language. The translation-method on the list of vocabularies, sets of grammar rules to producing the target language, translated passages from the second language to the memorization and written the first language and vice versa, and emphasizing the memorization and written language (Yule,2006,2010; Larsen-Freeman and Aderson, 2011), this method focused on students' ability to read and write the target language well. Richards and Theodore (2001) stated that the use of this translation is based on an assumption that grammar can be taught through direct instruction and repetitive practice. Furthermore, they pointed out that the use of tis method is as the opposite of the inductive approach. It means that the method will make a sentence based on the grammar rules given by the teachers, vocabulary is explained through the drilling activity, and the use of dictionary in the form of memorization. In order word, this method is a traditional method in the where students are taught follow what the teacher said and do.

\section{Language Learning}

Learning a foreign language is, of course, different from learning one's mother tang ue. There are three types of language items, which are introduce to a learners, first, phonological items which cover sound of the language. Second, lexical items, which discuss frequent repetition and exposure, and adopt memorization strategies when learning the lexical items. Third, structural items which include the rules of constructing sentences. Hubbard(1998).Second language learning takes places in a diversity of both formal and informal contexts, each of which reflects a different configuration of elements that shape the nature of interactions learner are engaged in. Oxford, R. (1990). In learning English, the learners have difference ability in comprehending the structural items. The learners are given the chance to apply their knowledge in grammar based on their ability.

\section{"English-Only" Policy}

Before now days. In the nineteenth century, many learning methods come against the grammar-translation method such as the audio -lingual method, communicative method and task - based learning methods. Those methods suggested that teachers should use language of native in teaching the target language. The "English-Only" method had been known by people all over the world (Deller and Rinvolucri, 2002). Audio- lingual method used drills and dialogues in teaching the spoken language, where it focuses more on their pronunciation on the target language. While the communicative method encourages the students to speak more as it concerns more on the language use appropriately rather that grammatical knowledge.

Task -based learning method is similar with the communicative method as it focuses on the use of language, so the students learn the language through their experience by using that language . according to Richards (2001), communicative language teaching (CLT) has some aspects. As the following below: 1) It helps the students to be able to use the language based on the setting and participants, such as when they use formal and informal speech or when to use language well for written communication and spoken. 2) It helps the students to be able to use the language based on the setting and participants. 3) It also helps the students produce and comprehend different kinds of text. For instance, narrative text, report text, and review text. 4) It helps them to communicative with many different people by using different kinds of communication strategies.Communicative and task-based learning method may give the opportunity to the students to be more active and critical since these two methods will let the students use and experience the language to understand it.

\section{Using English in Teaching and Learning Process}

Cook (2008) says that two reasons why first language should use less in teaching and learning English as Foreign Language (EFL) process. First, second language (L2) are the L1 learners. It means that when children are acquiring their first language, they do not have the other languages to rely on. More over, foreign language learners should ideally their L2 similar with the children do in their L1. Teachers must presume that as if the students do not have other language to rely on when they study and learn of the L2. It means that, the students should use the theirs L2 more to help them familiar with that language. So, they can use and practice the language more often. Second, both languages are independent. It is very a good idea to use both the languages L2 and L1 personally and independently. The benefits of use it for whose are learning their foreign language as they keep those languages apart in their mind. 
on the other hand, our mind is special and different place to store and managed language that we have learned. By using and keeping them in our mind, we are able to re call our memories everytime when we need it.

\title{
Advantages and Disadvantages Using English in Teaching and Learning Process
}

Harmer (2001) claims that as a teacher, the teachers should not to be conscious of students' usage or input but also aim the students to remember and recognize the language fact throughout the opportunities. The teachers are given to the students in language teaching. It is happened in teaching and learning process at the class room . it can be remains that the in the second language classroom where English in involved as the verbal communication at the class. For more information . it is also important in the second language learning process. Because plays an important rule in developing students' proficiency (Swain,2008).

Swain (2008) states that it is good idea to give the chance to the students to use L2 in the second language classroom to have good written and spoken input. Furthermore, students need to use English classroom. This statement is gorgeous mind or idea to applying in the teaching and learning process. The students have the enthusiastic moment when they get the new vocabulary. Finally, English will be familiar and they can use it as the new activity life, especially in teaching and learning process.

\begin{abstract}
Atitude
De Bot, Lowie and Verspoor (2005) stated that " teacher, learners and researchers will all the same reaction or unanimously that advanced motivation and a respectable attitude toward a second language and its community assist second language learning". While Baker (1988) claimed that the attitudes are not subject of legacy because they are internalized disposed. The attitudes in respect of certain language might be either positive or negative. Some students may have no positive attitude concerning the second language ( English) and want to study it in order to obtain over people in the social life or community but usually positive attitude confirm the motivation.Furthermore, some individual, person, or personal, might deliver pure feelings. It can be interesting when the other researcher believed that the attitudes towards a language are often reflected in the attitudes concerning the components of that speech community.

Fasold (1984).Montano and Kasprzyk (2008, p. 71) state,

"Attitude is determined by the individual's beliefs about outcomes or attributes of performing the behavior (behavioral beliefs), weighted by evaluations of those outcomes or attributes".

Thus, a person who holds strong beliefs that positively valued outcomes will result from performing the behavior will have a positive attitude toward the behavior. Conversely, a personwho holds strong beliefs that negatively valued outcomes will result from the behavior will have a negative attitude.
\end{abstract}

\section{Students Atitude}

Attitude can alter every aspect of a person's life, including their education. Student attitudes on learning determine their ability and willingness to learn. If negative attitudes are not altered, a student is unlikely to continue his education beyond what is required.

Shaw (1981) revealed that the students' attitudes that he found in many countries such as: 1) The language background of the students. 2) Their reasons for studying English.3) The pattern of their present and future use of English. 4) The English language skills they wish to develop.

Changing students' negative attitudes towards learning is a process that involves determining the factors driving the attitude and using this information to bring about change,namely : First, Features, how do educators determine student attitudes on learning? The answer is simple: they ask them When children lack motivation, they fail to grasp the material. The response is often anger, rebellion and even physical symptoms such as anxiousness and illness. Students at this age level seem to desire a positive attitude and the motivation to learn. Second, Function, once educators uncover student attitudes on learning, the challenge is using this information to shape a positive attitude. Adult students can see the future results of their learning, such as a better job and more money.

Third, Effect, Student attitudes on learning, good or bad, affect their outlook toward learning throughout life. Their attitude towards learning affected not only their amount of education but their desire for education.Fourt, Benefit, two teaching methods, Direct Teaching and Cooperative Learning, offer examples of how students are either motivated or discouraged by the teaching method. Direct Teaching is used to instill facts and master basic skills. Fifth, Consideration, Attitude is a learned behavior and, as such, is highly susceptible to change. The Behavioral Theory requires "positive reinforcement" or reward for good behavior. This theory is consistent with the attitudes toward learning, especially at an elementary level 


\section{METHODOLOGY}

This research is classified as aquantitative study with use survey method for collecting data. (Cresweell, 2012;Fraenkel and Wallen, 2009). Moreover, Cresswell (2012) claims that the researcher can mixed the data to provide better understanding rather than using one data only and the researcher uses this method when one of both qualitative and quantitative is not enough to answer the question in the research. They were a second semester students at Economic ( one class) and law (two classes) faculty. The have English subject in the second semester that is way will be chosen by the researcher. In addition, the researcher contacted them and just only 75 students who were joint in my research. The invitation of join to this research by used the social media (WhatsApp).

This research used questionnaires as the instruments to gather the data. Questionnaires is another kind of instruments used in tis research.The questionnaires consist of four specifications as stated, there are, attitude, behavioral, cognitive, and emotional. It is always related to the participant. They will seat as a group. Every group consist of 5-10 students. The make circle, the researcher will be a moderator and will give the instruction about the topic, ask each question to the participants, and control the discussion. Controlling the students to be focus on the discussion and prevent overlap among the members. Furthermore, the researcher will have rating scales to make the respondent easy to choose, and give their best answer.

\section{FINDINGS AND DISCUSSIONS}

Attitute through respondents' answers to statements submitted through questionnaires, measured by indicators that are operationalized into 10 questions. Respondents to each question can be seen in table 1 as follows:

Table 1. Description of the Attitudes Inuniversity of batanghari

\begin{tabular}{|c|c|c|c|c|c|c|c|c|}
\hline No & Pernyataan & 5 & 4 & 3 & 2 & 1 & Mean & Kategori \\
\hline \multicolumn{9}{|c|}{ ATTITUDES } \\
\hline 1 & $\begin{array}{l}\text { I think that studying English is } \\
\text { significant because it will make me } \\
\text { more educated }\end{array}$ & $\begin{array}{c}69 \\
55.2 \%\end{array}$ & $\begin{array}{c}44 \\
35.2 \%\end{array}$ & $\begin{array}{c}10 \\
8.0 \%\end{array}$ & - & - & 3,58 & High \\
\hline 2 & $\begin{array}{l}\text { For me, if I can be a good at English } \\
\text { it will help me to study other subjects. }\end{array}$ & $\begin{array}{c}53 \\
42.4 \%\end{array}$ & $\begin{array}{c}49 \\
39.2 \%\end{array}$ & $\begin{array}{c}18 \\
14.4 \%\end{array}$ & $\begin{array}{c}3 \\
2.4 \%\end{array}$ & - & 3,40 & High \\
\hline 3 & $\begin{array}{l}\text { I am so excited and happy when } \\
\text { studying English in the class }\end{array}$ & $\begin{array}{c}53 \\
42.4 \%\end{array}$ & $\begin{array}{c}47 \\
37.6 \%\end{array}$ & $\begin{array}{c}18 \\
14.4 \%\end{array}$ & $\begin{array}{c}5 \\
4.0 \%\end{array}$ & - & 3,60 & High \\
\hline 4 & $\begin{array}{l}\text { I am so glad when I use in English } \\
\text { with my friends }\end{array}$ & $\begin{array}{c}52 \\
41.6 \%\end{array}$ & $\begin{array}{c}43 \\
34.4 \%\end{array}$ & $\begin{array}{c}21 \\
16.8 \%\end{array}$ & $\begin{array}{c}3 \\
3.4 \%\end{array}$ & - & 3,61 & High \\
\hline 5 & I feel so nervous when I speak English & $\begin{array}{c}28 \\
22.4 \%\end{array}$ & $\begin{array}{c}45 \\
36 \%\end{array}$ & $\begin{array}{c}20 \\
16 \%\end{array}$ & $\begin{array}{c}11 \\
8.8 \%\end{array}$ & $\begin{array}{c}17 \\
13.6 \%\end{array}$ & 3,82 & High \\
\hline 6 & $\begin{array}{l}\text { Studying English make me happy } \\
\text { because I can use it in internet for } \\
\text { making friends }\end{array}$ & $\begin{array}{c}47 \\
37.6 \%\end{array}$ & $\begin{array}{c}14 \\
11.2 \%\end{array}$ & $\begin{array}{c}12 \\
9.6 \%\end{array}$ & $\begin{array}{c}14 \\
11.2 \%\end{array}$ & $\begin{array}{c}34 \\
27.2 \%\end{array}$ & 3,73 & High \\
\hline 7. & $\begin{array}{l}\text { I do not mind when I give comment } \\
\text { during English discussion. }\end{array}$ & $\begin{array}{c}53 \\
42.4 \%\end{array}$ & $\begin{array}{c}56 \\
44.8 \%\end{array}$ & $\begin{array}{c}8 \\
6.4 \%\end{array}$ & $\begin{array}{c}6 \\
4.8 \%\end{array}$ & - & 3,88 & High \\
\hline 8 & $\begin{array}{l}\text { I have more knowledge and more } \\
\text { comprehend when I studying English }\end{array}$ & $\begin{array}{c}28 \\
22.4 \%\end{array}$ & $\begin{array}{c}45 \\
36 \%\end{array}$ & $\begin{array}{c}20 \\
16 \%\end{array}$ & $\begin{array}{c}11 \\
8.8 \%\end{array}$ & $\begin{array}{c}17 \\
13.6 \%\end{array}$ & 4,46 & High \\
\hline 9 & $\begin{array}{l}\text { I want to increase my ability to } \\
\text { studying English in the future }\end{array}$ & $\begin{array}{c}47 \\
37.6 \%\end{array}$ & $\begin{array}{c}14 \\
11.2 \%\end{array}$ & $\begin{array}{c}12 \\
9.6 \%\end{array}$ & $\begin{array}{c}14 \\
11.2 \%\end{array}$ & $\begin{array}{c}34 \\
27.2 \%\end{array}$ & 3,91 & High \\
\hline 10 & $\begin{array}{l}\text { I feel confident when I answer the } \\
\text { question in my English class } \\
\text { Variable of ATTITUDES }\end{array}$ & $\begin{array}{c}53 \\
42.4 \% \\
\mathbf{3 5 5}\end{array}$ & $\begin{array}{c}56 \\
44.8 \% \\
\mathbf{2 9 8}\end{array}$ & $\begin{array}{c}8 \\
6.4 \% \\
\mathbf{1 0 7}\end{array}$ & $\begin{array}{c}6 \\
4.8 \% \\
\mathbf{4 2}\end{array}$ & $\begin{array}{c}- \\
51\end{array}$ & $\begin{array}{c}3,90 \\
\mathbf{3 , 8 6}\end{array}$ & Tinggi \\
\hline
\end{tabular}

From the above table, it can be explained that variable of attitudes of 10 statement items, there is one item in the very high category (8), the rest are all in the high category with a mean value on the range, $3.40-4.19$ overall, variable of attitudes is in the high category with an average value of 3.86 .

\section{Descriptive Analysis of Behavioral aspects}

Table 2. Perception of behavioral

\begin{tabular}{|c|c|c|c|c|c|c|c|c|}
\hline No & Pernyataan & 5 & 4 & 3 & 2 & 1 & Mean & Kategori \\
\hline \multicolumn{9}{|c|}{ Behavioral } \\
\hline 1 & $\begin{array}{l}\text { When my friends practice } \\
\text { speaking English well, I lwant to } \\
\text { do speaking with them. }\end{array}$ & $\begin{array}{c}69 \\
55.2 \%\end{array}$ & $\begin{array}{c}44 \\
35.2 \%\end{array}$ & $\begin{array}{c}10 \\
8.0 \%\end{array}$ & - & - & 3,93 & High \\
\hline
\end{tabular}




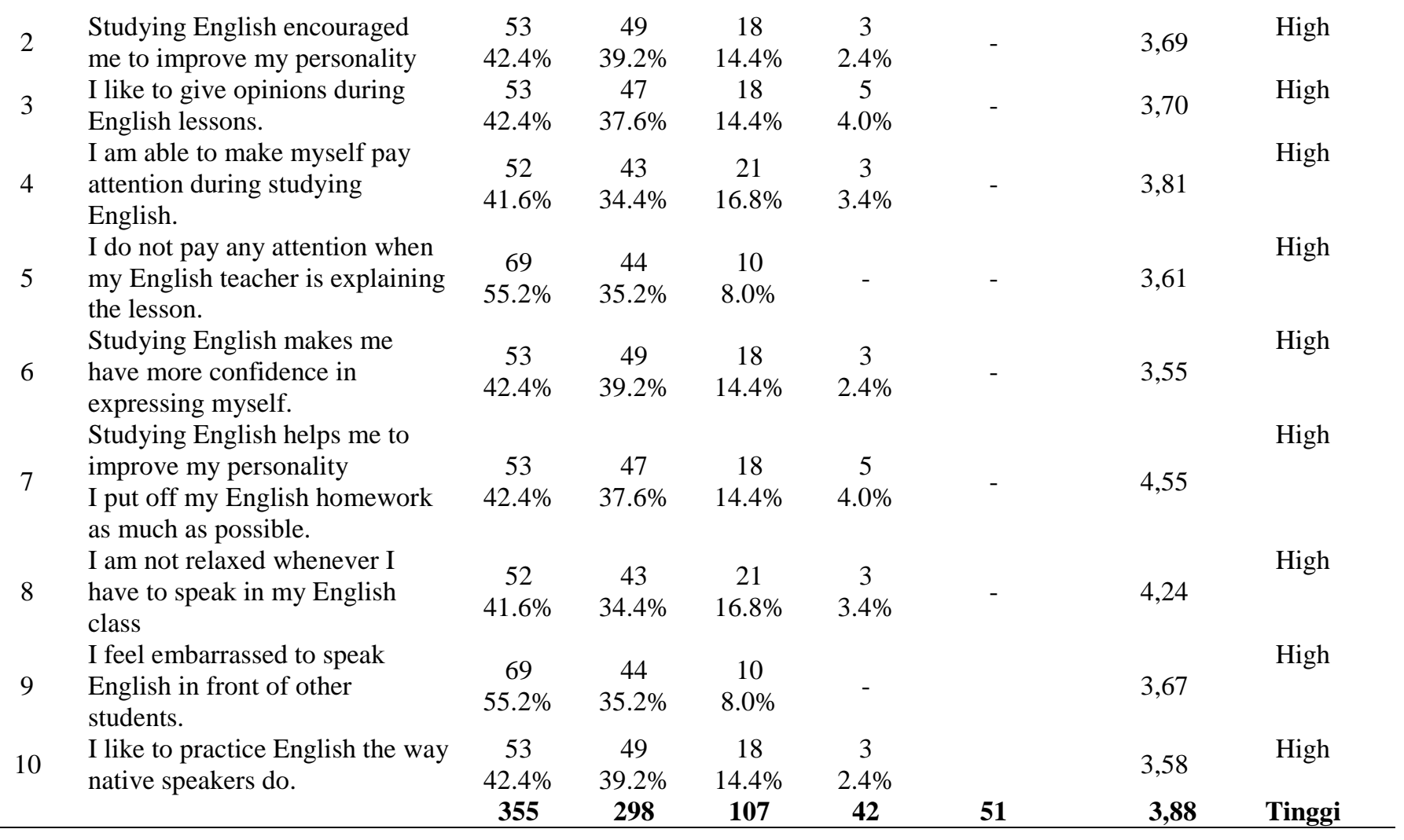

From the table above, it can be explained that the Variable of Behavioral of the 10 statement items is that one item is in the very high category (8). of Behavioral is in the high category with an average value of 3.88 .

\section{Descriptive Analysis of Cognitive aspects}

Table 3. Perception of COGNITIVES

\begin{tabular}{|c|c|c|c|c|c|c|c|c|}
\hline No & Pernyataan & 5 & 4 & 3 & 2 & 1 & Mean & Kategori \\
\hline \multicolumn{9}{|c|}{ Cognitives } \\
\hline 1 & $\begin{array}{l}\text { I cannot summarize the important } \\
\text { points in the English subject content } \\
\text { by myself. }\end{array}$ & $\begin{array}{c}69 \\
55.2 \%\end{array}$ & $\begin{array}{c}44 \\
35.2 \%\end{array}$ & $\begin{array}{l}10 \\
8.0 \%\end{array}$ & - & - & 3,60 & High \\
\hline 2 & $\begin{array}{l}\text { Frankly, I study English just to pass } \\
\text { the exams. }\end{array}$ & $\begin{array}{c}53 \\
42.4 \%\end{array}$ & $\begin{array}{c}49 \\
39.2 \%\end{array}$ & $\begin{array}{c}18 \\
14.4 \%\end{array}$ & $\begin{array}{c}3 \\
2.4 \%\end{array}$ & - & 3,46 & \multirow[b]{2}{*}{ High } \\
\hline 3 & $\begin{array}{l}\text { In my opinion, people who speak } \\
\text { more than one language are very } \\
\text { knowledgeable. }\end{array}$ & $\begin{array}{c}53 \\
42.4 \%\end{array}$ & $\begin{array}{c}47 \\
37.6 \%\end{array}$ & $\begin{array}{c}18 \\
14.4 \%\end{array}$ & $\begin{array}{c}5 \\
4.0 \%\end{array}$ & - & 3,54 & \\
\hline 4 & $\begin{array}{l}\text { I cannot apply the knowledge from } \\
\text { English subject in my real life. }\end{array}$ & $\begin{array}{c}69 \\
55.2 \%\end{array}$ & $\begin{array}{c}44 \\
35.2 \%\end{array}$ & $\begin{array}{l}10 \\
8.0 \%\end{array}$ & - & - & 3,60 & High \\
\hline 5 & $\begin{array}{l}\text { In my opinion, English language is } \\
\text { difficult and complicated to learn. }\end{array}$ & $\begin{array}{c}53 \\
42.4 \%\end{array}$ & $\begin{array}{c}49 \\
39.2 \%\end{array}$ & $\begin{array}{c}18 \\
14.4 \%\end{array}$ & $\begin{array}{c}3 \\
2.4 \%\end{array}$ & - & 3,81 & High \\
\hline 6 & $\begin{array}{l}\text { English subject has the content that } \\
\text { covers many fields of knowledge. }\end{array}$ & $\begin{array}{c}69 \\
55.2 \%\end{array}$ & $\begin{array}{c}44 \\
35.2 \%\end{array}$ & $\begin{array}{c}10 \\
8.0 \%\end{array}$ & - & - & 3,79 & High \\
\hline 7 & $\begin{array}{l}\text { Studying English makes me able to } \\
\text { create new thoughts. }\end{array}$ & $\begin{array}{c}53 \\
42.4 \%\end{array}$ & $\begin{array}{c}49 \\
39.2 \%\end{array}$ & $\begin{array}{c}18 \\
14.4 \%\end{array}$ & $\begin{array}{c}3 \\
2.4 \%\end{array}$ & - & 3,88 & High \\
\hline 8 & $\begin{array}{l}\text { I am not satisfied with my } \\
\text { performance in the English subject. }\end{array}$ & $\begin{array}{c}53 \\
42.4 \%\end{array}$ & $\begin{array}{c}47 \\
37.6 \%\end{array}$ & $\begin{array}{c}18 \\
14.4 \%\end{array}$ & $\begin{array}{c}5 \\
4.0 \%\end{array}$ & - & 4.69 & High \\
\hline 9 & $\begin{array}{l}\text { In my opinion, English language is } \\
\text { difficult and complicated to learn. }\end{array}$ & $\begin{array}{c}69 \\
55.2 \%\end{array}$ & $\begin{array}{c}44 \\
35.2 \%\end{array}$ & $\begin{array}{l}10 \\
8.0 \%\end{array}$ & - & - & 3,64 & High \\
\hline 10 & English subject has the content that & $\begin{array}{c}53 \\
42.4 \%\end{array}$ & $\begin{array}{c}49 \\
39.2 \%\end{array}$ & $\begin{array}{c}18 \\
14.4 \%\end{array}$ & $\begin{array}{c}3 \\
2.4 \%\end{array}$ & - & 3,67 & High \\
\hline & & 355 & 298 & 107 & 42 & 51 & $\mathbf{3 , 9 7}$ & High \\
\hline
\end{tabular}


From the table above, we can explain QUESTIONAIRES OF COGNITIVES from 10 statement items, there is one item in the very high category (8), all items are in the high category with average values in the range, $3.40-4.19$ overall, QUESTIONAIRES OF COGNITIVE is in the high category with an average value of 3.97.

\section{Descriptive Analysis of Emotional aspects}

\begin{tabular}{|c|c|c|c|c|c|c|c|c|}
\hline No & Pernvataan & 5 & 4 & 3 & 2 & 1 & M & Kateoniri \\
\hline 1 & $\begin{array}{l}\text { Studying English makes me have } \\
\text { good emotions (feelings) }\end{array}$ & $\begin{array}{c}69 \\
552 \%\end{array}$ & $\begin{array}{c}44 \\
35.2 \%\end{array}$ & $\begin{array}{c}10 \\
80 \%\end{array}$ & - & - & 3,66 & High \\
\hline 2 & $\begin{array}{l}\text { To be inquisitive makes me study } \\
\text { English well. }\end{array}$ & $\begin{array}{c}53 \\
42.4 \%\end{array}$ & $\begin{array}{c}49 \\
39.2 \%\end{array}$ & $\begin{array}{c}18 \\
14.4 \%\end{array}$ & $\begin{array}{c}3 \\
2.4 \%\end{array}$ & - & 3,25 & High \\
\hline 3 & I enjoy doing activities in English. & $\begin{array}{c}53 \\
42.4 \%\end{array}$ & $\begin{array}{c}47 \\
37.6 \%\end{array}$ & $\begin{array}{c}18 \\
14.4 \%\end{array}$ & $\begin{array}{c}5 \\
4.0 \%\end{array}$ & - & 3,73 & High \\
\hline 4 & $\begin{array}{l}\text { I wish I could speak English } \\
\text { fluently. }\end{array}$ & $\begin{array}{c}53 \\
42.4 \%\end{array}$ & $\begin{array}{c}49 \\
39.2 \%\end{array}$ & $\begin{array}{c}18 \\
14.4 \%\end{array}$ & $\begin{array}{c}3 \\
2.4 \%\end{array}$ & $\begin{array}{c}53 \\
42.4 \%\end{array}$ & 3,72 & High \\
\hline 5 & $\begin{array}{l}\text { I not to confident when my friend } \\
\text { ask me by using English }\end{array}$ & $\begin{array}{c}53 \\
42.4 \%\end{array}$ & $\begin{array}{c}47 \\
37.6 \%\end{array}$ & $\begin{array}{c}18 \\
14.4 \%\end{array}$ & $\begin{array}{c}5 \\
4.0 \%\end{array}$ & $\begin{array}{c}53 \\
42.4 \%\end{array}$ & 3,43 & High \\
\hline 6 & $\begin{array}{l}\text { I prefer studying in my mother } \\
\text { tongue rather than any other foreign } \\
\text { language. }\end{array}$ & $\begin{array}{c}53 \\
42.4 \%\end{array}$ & $\begin{array}{c}49 \\
39.2 \%\end{array}$ & $\begin{array}{c}18 \\
14.4 \%\end{array}$ & $\begin{array}{c}5 \\
4.0\end{array}$ & $\begin{array}{c}53 \\
42.4 \%\end{array}$ & 3,73 & High \\
\hline 7 & $\begin{array}{l}\text { Studying English makes me have } \\
\text { good emotions (feelings). }\end{array}$ & $\begin{array}{c}69 \\
55.2 \%\end{array}$ & $\begin{array}{c}44 \\
35.2 \%\end{array}$ & $\begin{array}{c}10 \\
8.0 \%\end{array}$ & - & - & 3,64 & High \\
\hline 8 & $\begin{array}{l}\text { I look forward to the time I spend in } \\
\text { English class. }\end{array}$ & $\begin{array}{c}53 \\
42.4 \%\end{array}$ & $\begin{array}{c}49 \\
39.2 \%\end{array}$ & $\begin{array}{c}18 \\
14.4 \%\end{array}$ & $\begin{array}{c}3 \\
2.4 \%\end{array}$ & - & 3,91 & High \\
\hline 9 & I am interested in studying English. & $\begin{array}{c}53 \\
42.4 \%\end{array}$ & $\begin{array}{c}47 \\
37.6 \%\end{array}$ & $\begin{array}{c}18 \\
14.4 \%\end{array}$ & $\begin{array}{c}5 \\
4.0 \%\end{array}$ & - & 3,82 & High \\
\hline 10 & $\begin{array}{l}\text { To be honest, I really have little } \\
\text { interest in my English class. }\end{array}$ & $\begin{array}{c}53 \\
42.4 \% \\
\mathbf{3 5 5}\end{array}$ & $\begin{array}{l}49 \\
39.2 \% \\
\mathbf{2 9 8}\end{array}$ & $\begin{array}{c}18 \\
14.4 \% \\
\mathbf{1 0 7}\end{array}$ & $\begin{array}{l}3 \\
2.4 \% \\
\mathbf{4 2}\end{array}$ & $\begin{array}{c}53 \\
42.4 \% \\
\mathbf{5 1}\end{array}$ & $\begin{array}{r}3,58 \\
\mathbf{3 , 8 5}\end{array}$ & High \\
\hline
\end{tabular}

From the above table, we can explain questionaires of emotional from 10 statement items, there is one item in the very high category (8), the rest are in the high category with average values in the range, $3.40-4.19$ overall, questionaires of emotional is in the high category with an average value of 3.85 .

Percentage Result Table non - English Major Students 'Attitudes Toward English Lesson at Batanghari University
\begin{tabular}{|c|c|c|}
\hline Dimensi & SKOR & KATEGORI \\
\hline Attitute & 3,74 & High \\
BEHAVIORAL & 3,88 & High \\
COGNITIVE & 3,97 & High \\
EMOTIONAL & 3.85 & High \\
\hline
\end{tabular}

\section{Perception of The Students}

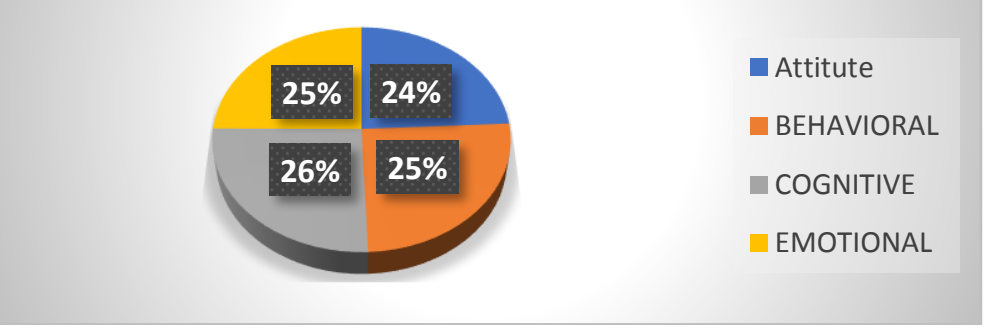

From the above data it can be seen that all variables are included in the high category and only one indicator is the highest, the Cognitive indicator.

De Bot, Lowie and Verspoor (2005) stated that " teacher, learners and researchers will all the same reaction or unanimously that advanced motivation and a respectable attitude toward a second language and its community assist 
second language learning". While Baker (1988) claimed that the attitudes are not subject of legacy because they are internalized disposed. The attitudes in respect of certain language might be either positive or negative. Some students may have no positive attitude concerning the second language (English) and want to study it in order to obtain over people in the social life or community but usually positive attitude confirm the motivation. Furthermore, some individual, person, or personal, might deliver pure feelings. It can be interesting when the other researcher believed that the attitudes towards a language are often reflected in the attitudes concerning the components of that speech community.

\section{CONCLUTIONS AND SUGESTIONS \\ Conclusion}

Based on the data provided, it can be explained that variable of attitudes out of 10 statement items, there is one item in the very high category $\mathrm{g}(8)$, the rest are all in the high category with a mean value in the range, $3.40-4.19$ overall, variable of attitudes is in the high category with an average value of 3.86. Next, it can be explained that the Variable of Behavioral of the 10 statement items contains one item in the very high category (8), the rest are all in the high category with a mean value in the range, $3.40-4.19$ overall, Variable of Behavioral is in the high category with an average value of 3.88. Then, we can explain QUESTIONAIRES OF COGNITIVES from 10 statement items, there is one item in the very high category (8), all items are in the high category with average values in the range, 3.40 4.19 overall, QUESTIONAIRES OF COGNITIVE is in the high category with an average value of 3.97. Next, we can explain QUESTIONAIRES OF EMOTIONAL from 10 statement items, there is one item in the very high category (8), the rest are in the high category with average values in the range, $3.40-4.19$ overall, QUESTIONAIRES OF EMOTIONAL is in the high category with an average value of 3.85 .

\section{Suggestions}

Lecturers are advised to be able to memertahakan and improve the performance that has been achieved do not be quickly satisfied with what has been achieved and improve and maintain motivation in improving the quality of the learning process in order to create good and conducive learning environment, School supervisors are advised to be able to maintain what has been achieved when this and continue to improve attitudes, behavior, emotional and knowledge and so forth and provide examples and examples for teachers and guide teachers in creating better learning processes going forward by prioritizing policies and steps that are congruent in improving teacher performance, although in research the author does not provide a negative assessment, to improve the quality of education the author believes it is necessary to conduct further research on other factors that also influence the learning outcomes. Because as has been stated above that found other factors that also influence teacher performance that we cannot ignore.

\section{REFERENCES}

Abidin, M. J. Z., Pour-Mohammadi, M., \& Alzwari, H. (2012). EFL students' attitudes towards learning English language: The case of Libyan secondary school students. Asian social science, 8(2), 119.

Akhmeed, Shameem. (2015).Attitude Towards English Language Learning Among EFL Learners at UMSKAL. Journal of Education and Practice ISSN 2222-1735 (Paper) ISSN 2222-288X (Online) Vol.6, No.18, 2015

Ary, Donald.Etall,2002.Introduction to Research in Education.(6 ${ }^{\text {th }}$ ED).USA:Wadsworth

Baker, C. (1988). Key issues in bilingualism and bilingual education. Multilingual Matters 35. Clevedon, Avon: England

Chalak, A., \& Kassaian, Z. (2010). Motivation and attitudes of Iranian undergraduate EFL students towards learning English. GEMA Online ${ }^{\circledR}$ Journal of Language Studies, 10(2).

Cook, V.(2008). Second Language Learning and Language Teaching $\left(4^{\text {th }}\right.$ Ed). London: Hodder Education

Cohen, L., Manion, L., \& Morisson., K. (2005). Research Methods in education $\left(5^{\text {th }}\right.$ Ed). London: Routledge.

Creswell, W.J.(2012)Educational Research Planning, Conducting,and Evalutaing Quatitative and Qualitative Research $\left(4^{\text {th }} \mathrm{Ed}\right)$.Boston: Person Education.

Dawson, C.(2002). Practical Research method: A User- Friendly Guide to Mastering Research Techniques and Projects. United Kingdom :How To Books Ltd.

De Bot, K., Lowie, W. \& Verspoor, M. (2005). Second language acquisition: An advanced resource book. London: Routledge.

Dörnyei, Z. \& Taguchi, T. (2010). Questionnaires in Second Language Research: Construction, Administration, and Processing. 2nd Edition. UK: Routledge

Fasold, R. (1984). The sociolinguistics of society. Oxford: Blackwell.

Gardner, R. C., \& Lambert, W.E. (1972). Attitude and Motivation in Second Language Learning. Rowley, Mass.: Newbury House. 
Harmer, J. (2001). The Practice of English Language Teaching ( $3^{\text {rd }}$ Ed). London: Longman

Harmer, J. (2008). How to teach English. ELT journal, 62(3), 313-316.

Marczyk, G., Dematteo, D.,\& Festtinger, D. (2005). Essentials of Research Design and Methodology. New Jersey: Jhon Wiley \& Sons.

Mirabela, Anamaria, Pop. „\& Ariana, Monica, Sim. (2016).Benefit of English language Learning -Language Proficiency Certificates - A Prerequisites for the Business Graduate. Journal http://steconomiceuoradea.ro/anale/volume/2013/n2/016.pdf

Montano, D. E. \& Kasprzyk, D. (2008). Theory of reasoned action, theory of planned behavior, and the integrated behavioral model. In K. Glanz, B. Rimer \& K. Viswanath (Eds.), Health behavior and health education: Theory, research, and practice. San Francisco, CA: Jossey-Bass, 67-96.

NGOC, K. M., \& Iwashita, N. O. R. I. K. O. (2012). A comparison of learners' and teachers' attitudes toward communicative language teaching at two universities in Vietnam. University of Sydney Papers in TESOL, 7.

Oxford, R. (1990). Language learning strategies. New York, 3.

Shaw, W. D. (1981). Asian student attitudes towards English. In English for cross-cultural communication (pp. 108122). Palgrave Macmillan, London.

Williams, Eira. (2006).Students Attitudes Towards Approaches to Learning and Assessment. Journal Assesment and Evaluation in Higher Education. Volume 17,1992-Issue 1 